
Bell, P., Homatas, J., MacSween, R., and Brettschneider, L. (1969). Surgical

Calne, R. Y. (1969). British fournal of Surgery, 56, 729.

Calne, R. Y., and Williams, R. (1968). British Medical fournal, 4, 535.

Calne, R. Y. et al. (1968). British Medical fournal, 4, 541.

Calne, R. Y., et al. (1969). Nature, 223, 472.

Calne, R. Y., Shackman, R., Nolan, B., Petrie, J., and Woodruff, M.'(1970). Lancet, 1,671 .
Lawrence, G. H., Grauman, D., Lasersohn, J, and Baker, J. W. (1966). American fournal of Surgery, 112, 200.

Nelson, R. S., de Elizalde, R., and Howe, C. D. (1966). Cancer (Philadelphia), $19,533$.

Orr, W. McN., et al. (1969). British Medical fournal, 4, 28.

Williams, R. (1970). British Medical fournal, 1, 585.

Williams, R., et al. (1969). British Medical fournal, 3, 12.

\title{
Thromboembolic Complications in Myelomatosis
}

\author{
D. CATOVSKY,* M.D. ; N. B. IKOKU, † м.B., B.CH. ; W. R. PITNEY,† M.D., F.R.A.C.P. ; D. A. G. GALTON, $\$ M.D., F.R.C.P.
}

British Medical fournal, 1970, 3, 438-439

\begin{abstract}
Ummary: Fourteen cases of myelomatosis associated $\checkmark$ with major thromboembolic complications are reported. Six patients died of pulmonary embolism, seven had deep-vein thrombosis as a presenting symptom, and three had evidence of amyloidosis. A preliminary estimate of the incidence of thromboembolism based on 376 patients admitted so far to the Medical Research Council's myelomatosis trial is about $3 \%$, while pulmonary embolism accounted for about $3 \%$ of all deaths. Possibly a hypercoagulable state and the presence of amyloidosis may be important in the pathogenesis of this complication.
\end{abstract}

\section{Introduction}

While haemorrhage is common in myelomatosis, especially in the terminal stages, thromboembolism is not a well-recognized complication. Nevertheless, we have recently seen five patients suffering from deep-vein thrombosis, associated in four with pulmonary embolism, in three of whom a diagnosis of myelomatosis was made subsequent to the development of thromboembolism. Nine further cases of thrombosis have been found in the records of the Medical Research Council's myelomatosis trial.

\section{Case Reports}

Brief clinical and laboratory findings in the 14 patients are shown in the Table. Venous thrombosis or pulmonary embolism was the presenting feature of the illness in seven patients, and in these myelomatosis was diagnosed on the basis of laboratory investigations. In another four patients thrombosis occurred two months or less after diagnosis. Pulmonary embolism was the cause of death in six patientsthree died five weeks or less after the diagnosis of myelomatosis was established, while in the other three pulmonary embolism caused death 6, 12, and 42 months after diagnosis. Thus five of the six fatalities from pulmonary embolism occurred in the first year after clinical recognition of the disorder. Twelve patients are among those admitted to the therapeutic trial in myelomatosis conducted by the Medical Research Council's Working Party on Leukaemia in Adults. By 15 March 1970, 376 patients had been entered to the trial, indicating a minimum incidence of thrombotic complications of $3.2 \%$. This figure would be higher if any of the surviving patients were to develop thromboembolism. By December

\footnotetext{
* Research Fellow, Department of Hasmatology, Royal Postgraduate Medical School, London W.12.

† Clinical Research Assistant, Leukaemia Trials Officc, Royal Marsden Hospital. London S.W.3. ‡ Reader in Haematology, Royal Postgraduate Medical School, London SReader (Hon.) in Haematology, Royal Postgraduate Medical School.
London W.12.
}

1969, 192 patients had died, six of them (3.1\%) from pulmonary embolism. Only 53 necropsies were performed, so it is possible that this figure is an underestimate. In seven patients $(1.8 \%)$ the first presenting feature of myelomatosis was thromboembolism.

\section{Discussion}

There are only a few reports of thromboembolism complicating myelomatosis in the literature. In a clinicopathological study of myelomatosis Talerman (1969) found that massive pulmonary embolism was the cause of death in 3 out of 32 necropsies; he had not found this cause of death previously reported. Sanchez-Avalos et al. (1969), searching for this complication in a clinical survey, recorded episodes of pulmonary embolism in 3 out of 34 patients. Two other cases were mentioned by Lieberman et al. (1961), in one of which venous thrombosis had been present for nearly three years kefore the diagnosis of myelomatosis was established.

The mechanism of thrombosis in myelomatosis remains uncertain. Sanchez-Avalos et al. (1969) reported that certain laboratory findings were associated with thrombotic phenomena in myelomatosis-namely a shortening of the coagulation time in silicone tubes and an increase in the plasma fibrinogen concentration, suggesting the presence of a hypercoagulable state. An appreciable increase in the plasma concentration of fibrinogen $(847 \mathrm{mg} . / 100 \mathrm{ml}$.) and factor VIII $(520 \%$ of standard normal) was found in one of our three patients (Case 3) in whom coagulation studies were made. High fibrinogen levels have been reported in myelomatosis, especially with IgG paraprotein (Viala et al., 1963; Niléhn and Nilsson, 1966). Plasma fibrinogen estimations however, may not be accurate in this condition owing to conjugation of the paraprotein with fibrinogen or occlusion in the fibrin clot (Bang, 1967; Regoeczi, 1968; Sanchez-Avalos et al., 1969). In either case measurement of fibrinogen as thrombin-clottablc protein would overestimate the true value. An increase in factor VIII has been found in myelomatosis as well as in other types of hyperglobulinaemia (Pitney and Elliott, 1960; Propp and Dylong, 1965; Niléhn and Nilsson, 1966). Increases in plasma fibrinogen and factor VIII have also been reported in patients with carcinoma (Mider et al., 1950; Amundsen et al., 1963). Davis et al. (1969), however, found that raised fibrinogen and factor VIII occurred in a number of non-malignant disorders and were not specific for malignant disease.

Malignant diseases, especially carcinoma, predispose to thrombosis (Lieberman et al., 1961; Miller et al., 1967; Wiernik and Serpick, 1969). In some types of carcinoma, especially carcinoma of the pancreas, the incidence is very high. Different histological types of pancreatic carcinoma however, are associated with pronounced differences in the incidence of multiple thrombi (Lafler and Hinerman, 1961). It 
Details of Cases

\begin{tabular}{|c|c|c|c|c|c|}
\hline $\begin{array}{l}\text { Case } \\
\text { No. }\end{array}$ & $\begin{array}{l}\text { Age } \\
\text { and } \\
\text { Sex }\end{array}$ & Thromboembolic Complication & $\begin{array}{l}\text { Time-relationship to } \\
\text { Diagnosis }\end{array}$ & Paraprotein & $\begin{array}{l}\text { Skeletal } \\
\text { Lesions }\end{array}$ \\
\hline 1 & $65 \mathrm{M}$. & D.V.T. in common femoral vein & Presenting feature & IgAL & Not seen \\
\hline 2 & $54 \mathrm{M}$. & Multiple D.V.T. and pulmonary embolism & " & IgAL & " " \\
\hline 3 & $76 \mathrm{M}$. & Repeated pulmonary infarcts, left renal vein thrombosis & ” & IgGK & " " \\
\hline 4 & $52 \mathrm{~F}$. & $\begin{array}{l}\text { Right internal and popliteal arterial occlusion. } \\
\text { Embolectomy. } \\
\text { Died of pulmonary embolism }\end{array}$ & $\begin{array}{l}2 \text { months after } \\
6 \text { months after }\end{array}$ & IgGL & Present \\
\hline 5 & $60 \mathrm{M}$. & Bilateral D.V.T. of calves & Presenting feature & IgGK & Not seen \\
\hline 6 & $56 \mathrm{M}$. & D.V.T. and repeated pulmonary infarcts & " & IgGL & Present \\
\hline 7 & $75 \mathrm{M}$. & Sudden arterial thrombosis in both lower limbs. Died of pulmonary embolism & 12 months after & IgGL & " \\
\hline 8 & $64 \mathrm{M}$. & $\begin{array}{l}\text { D.V.T. in right leg. } \\
\text { Died of massive pulmonary embolism }\end{array}$ & $\begin{array}{l}2 \text { weeks after } \\
4 \text { weeks after }\end{array}$ & IgGK & $\begin{array}{l}X \text {-ray films } \\
\text { not taken }\end{array}$ \\
\hline 9 & $61 \mathrm{M}$. & $\begin{array}{l}\text { D.V.T. in left leg. } \\
\text { Died of pulmonary embolism }\end{array}$ & $\begin{array}{l}3 \text { weeks after } \\
4 \text { weeks after }\end{array}$ & IgGK & Present \\
\hline 10 & $54 \mathrm{~F}$. & Sudden death due to pulmonary embolism & 5 weeks after & IgGL & " \\
\hline 11 & $36 \mathrm{~F}$. & Died of pulmonary embolism & $3 \frac{1}{2}$ years after & Bence Jones protein (type $\mathrm{K}$ ) & " \\
\hline 12 & $70 \mathrm{~F}$. & $\begin{array}{l}\text { Thrombosis in adrenal and vesical veins, pulmonary embolism. Died of renal } \\
\text { failure }\end{array}$ & 4 months after & IgGL & Not seen \\
\hline 13 & $73 \mathrm{~F}$. & Sequential D.V.T. in femoral veins & Presenting feature & IgGL & Present \\
\hline 14 & $61 \mathrm{M}$. & Multiple pulmonary embolism & " & IgGK & " \\
\hline
\end{tabular}

has been suggested that the same abnormalities which lead to an increased incidence of thrombosis in other types of disseminated malignant disease might be present in myelomatosis also (Miller et al., 1967). Sanchez-Avalos et al. (1969) suggested that the release of small amounts of thromboplastic material by the tumour cells may result in accelerated consumption of some coagulation factors and, in consequence, a compensatory overproduction. The resulting disturbance in the proportion of the coagulation factors may lead to haemorrhage or thrombosis. Both tendencies are present in myelomatosis, sometimes even in the same patient (Sanchez-Avalos et al., 1969).

The frequency of amyloid deposits in myelomatosis has been estimated to be between 6 and $15 \%$ (Cohen, 1967). Three of our patients (Cases 3, 4, and 12) with the nephrotic syndrome had evidence of amyloidosis in rectal or renal biopsies. The nephrotic syndrome due to renal amyloidosis has often been associated with renal vein thrombosis (Harrison et al., 1956; Barclay et al., 1960). Thrombosis is also not an uncommon complication of primary systemic amyloidosis, and this condition appears to be related to myelomatosis, both disorders forming part of a spectrum known as "plasma cell dyscrasias" (Osserman and Fahey, 1968). Barth et al. (1969) described thromboembolism in a patient with primary systemic amyloidosis, and two similar cases have been studied recently at the Royal Postgraduate Medical School. One of these patients died with thrombosis of the portal, splenic, and superior mesenteric veins, while the other suffered from repeated episodes of arterial embolism and died of renal failure due to bilateral renal vein thrombosis. Disseminated intravascular coagulation has also been reported in association with primary systemic amyloidosis (Bowie et al., 1969), and we have studied a similar case.

Possibly both a hypercoagulable state and amyloidosis may predispose to thromboembolism in myelomatosis. The incidence of thromboembolism has perhaps been underestimated in the past. When investigating a case of thromboembolic disease the possibility of myelomatosis and of amyloidosis should be considered. We have shown in the present series that, as in other malignant conditions, the thrombotic symptoms are often the initial manifestation of an otherwise un- suspected disease. In other patients, however, thromboembolism may occur in a more advanced stage of the disease and may be the cause of death.

We are grateful to Dr. R. Penny, Dr. P. J. L. Holt, and Mr. P. Martin for referring patients; to the M.R.C. Working Party on Leukaemia in Adults for permission to include cases from the Myelomatosis Trial; to Dr. R. B. Thompson and Dr. D. J. Evans for helpful information in Cases 12 and 13; and to Professor C. C. Booth, Dr. D. K. Peters, and Dr. K. Henry for permission to refer to two of their cases in the discussion. D. C. has a fellowship from the Consejo Nacional de Investigaciones Cientificas $y$ Técnicas de la R. Argentina. N. B. I. has a Medical Research Council grant.

\section{REFERENCES}

Amundsen, M. A., Spittell, J. A., Thompson, J. H., jun., and Owen, C. A., jun. (1963). Annals of Internal Medicine, 58, 608

Bang, N. U. (1967). In Blood Clotting Enzymology, ed. W. H. Seegers, p. 487. New York, Academic Press.

Barclay, G. P. T., Cameron, H. MacD., and Loughbridge, L. W. (1960). Quarterly fournal of Medicine, 29, 137.

Barth, W. F., Willerson, J. T., Waldmann, T. A., and Decker, J. L. (1969). American fournal of Medicine, 47, 259.

Bowic, E. J. W., Maldonado, J. E., Brown, A. L., Didisheim, P., and Owen, C. A., jun. (1969). Thrombosis et Diathesis Haemorrhagica, Suppl. No. 36, p. 305.

Cohen, A. S. (1967). New England fournal of Medicine, 277. 574.

Davis, R. B., Theologides, A., and Kennedy, B. J. (1969). Annals of Internal Medicine, 71, 67.

Harrison, C. V., Milne, M. D., and Steiner, R. E. (1956). Quarterly Fournal of Medicine, 25, 285

Lafler, C. J., and Hinerman, D. L. (1961). Cancer (Philadelphia), 14,

Licberman. J. S., Borrero, J., Urdaneta, E., and Wright, I. S. (1961). fournal of the American Medical Association, 177, 542.

Mider, G. B., Alling, E. L., and Morton, J. J. (1950). Cancer (Philadelphia', 3, 56.

Miller, S. P., Sanchez-Avalos, J., Stefanski, T., and Zuckerman, L. (1967). Cancer (Philadelphia), 20, 1452.

Niléhn, J. E., and Nilsson, I. M. (1966). Acta Medica Scandinavica, Suppl. No. 445 , p. 194.

Osserman, E. F., and Fahey, J. L. (1968). American fournal of Medicine, 44, 256 .

Pitney, W. R., and Elliott, M. H. (1960). Nature, 185, 397.

Pitney, W. R., and Elliott, M. H. (1960). Nature, 185,
Propp, S., and Dylong, V. M. (1965). Nature, 207, 206.

Propp, S., and Dylong, V. M. (1965). Nature, 207, 206. 27.

Sanchez-Avalos, J., Soong. B. C. F.. and Miller, S. P. (1969). Cancer (Philadelphia), 23, 1388

Talerman, A. (1969). British fournal of Cancer, 23, 285.

Viala, J. J., Thouverez, J. P., Belleville, J., Revol, L., and Croizat, P. (1963). Hémostase, 3, 303.

Wiernik, P. H., and Serpick, A. A. (1969). Cancer (Philadelphia), 24, 